\title{
Spatial Planning in Ghana: Antecedents and the Role of Local Artisans
}

\author{
Devine Hedidor¹, Francis Kwesi Bondinuba², Mohammed Abdulai Sadique ${ }^{3}$ \\ ${ }^{1}$ Oboadaka Local Authority Junior High School, Akuapim South District, Nsawan, Ghana \\ ${ }^{2}$ Institute for Social Policy, Housing, Environment and Real Estate, School of Energy, Geoscience, Infrastructure and Society, Heriot-Watt \\ University, Edinburgh, UK \\ ${ }^{3}$ Department of Building Technology, School of Engineering, Tamale Polytechnic, Tamale, Ghana \\ Email: d.hedidor@yahoo.co.uk, fkb30@hw.ac.uk,munsaqltd@hotmail.co.uk
}

How to cite this paper: Hedidor, D., Bondinuba, F.K. and Sadique, M.A. (2016) Spatial Planning in Ghana: Antecedents and the Role of Local Artisans. Journal of Building Construction and Planning Research, 4, 201-218.

http://dx.doi.org/10.4236/jbcpr.2016.43013

Received: July 5, 2016

Accepted: September 16, 2016

Published: September 19, 2016

Copyright $\odot 2016$ by authors and Scientific Research Publishing Inc. This work is licensed under the Creative Commons Attribution International License (CC BY 4.0).

http://creativecommons.org/licenses/by/4.0/ (c) (i) Open Access

\begin{abstract}
This paper explored the antecedents and the role of local artisans in Spatial Planning (SP) activities in Ghana. The paper was based on the results of an inspection of 5896 already built houses at Mepe in the Volta Region of Ghana. A mixed method research approach was used to gather the data through snowball non-probability sampling technique. It enabled the researchers to identify 100 local artisans. Survey questionnaires were used, which was followed by structured interviews with five (5) elders who lived in the town for over 65 years. The results showed that the early houses were built on community lands with mud and thatch clustered with narrow and unnamed alleys. Property owners heavily depended on local artisans for professional guidance, although some artisans were ill-trained and unaware of existing government SP regulations. The study was limited to artisans who practiced at the local community level. The findings showed that many local artisans were poorly trained, resulting in poor workmanship and non-compliance with local planning regulations. The paper recommends the integration of SP into the artisanal curricula at both local and national levels to improve their skills.
\end{abstract}

\section{Keywords}

Artisans, Ghana, Spatial Planning, Sustainability, Urbanism, Construction Industry

\section{Introduction}

There is an indication that the concept of SP is a very crucial aspect in ensuring economic, social and environmental harmony in urban cities. From a sustainability perspective, [1] posits that urban space design can improve sustainability and the quality of life in warm climates. There are therefore proven methods of environmental cooling 
that includes urban greening, increasing openness to allow cooling winds and the use of reflective materials that absorbed less solar radiation. The Ghana National Spatial Development Framework 2015-2035 Volume II [2] suggested that SP was critical for delivering economic, social and environmental benefits by creating more stable and predictable conditions for investment, development and by securing community benefits from those developments. Thus, SP is an important lever for promoting sustainable development and improving the quality of life as it is becoming increasingly recognized in international policy documents. SP can also help foster economic growth and investment while guiding policies for protecting the environment and promoting more efficient use of resources. Table 1 shows the sustainability dimensions of adopting proper SP in urban planning. [3] stated that SP enhanced a city's livability. They further noted that a well laid out mass transit system required considerably less physical space than private automobiles (transit: $0.75-2.5 \mathrm{~m}^{2} / \mathrm{cap}$; auto: $21-28 \mathrm{~m}^{2} / \mathrm{cap}$ ). Despite the above plethora of literature on the subject in both developed and developing countries, its relevance is very limited especially among local artisans in Ghana. This is due to lack of appropriate training and recognition of the role this segment of technical set plays in relation to SP. In the light of the above, this paper reports on the results of an inspection survey conducted on 5896 resettlement project in Mepe Township in the Volta region of Ghana.

The study revealed that Mepe had no spatial master plan. There is absolutely no town or village model showing the future location of streets, alleys, wastewater pipelines, residential and commercial areas, underground telecommunication cables, educational facilities, public utilities or the relationship between public spaces and buildings.

Table 1. The Sustainability Dimensions of SP.

\begin{tabular}{|c|c|c|}
\hline Economic benefits & Social benefits & Environmental benefits \\
\hline $\begin{array}{l}\text { - Provides stability and } \\
\text { confidence for investment. } \\
\text { - Identify land in appropriate } \\
\text { locations for economic } \\
\text { development } \\
\text { - Ensure that land for } \\
\text { development is well placed } \\
\text { - Promotes } \\
\text { environmentalquality in both } \\
\text { urban and rural areas } \\
\text { - Identify development that } \\
\text { meets the needs of local } \\
\text { communities } \\
\text { Promoteregeneration and } \\
\text { renewal } \\
\text { Make decisions in a more } \\
\text { efficient and consistent way }\end{array}$ & $\begin{array}{l}\text { - Considers the needs of the } \\
\text { local communities in } \\
\text { policy development } \\
\text { - Improve accessibility when } \\
\text { considering the location of } \\
\text { new development } \\
\text { - Supports the provision of } \\
\text { local facilities where they } \\
\text { are lacking } \\
\text { Promotes the reuse of va- } \\
\text { cant and derelict land, } \\
\text { where it impact on quality } \\
\text { of life and economic } \\
\text { development potential; } \\
\text { and } \\
\text { Aids the creation and } \\
\text { maintenance of pleasant, } \\
\text { healthy and safe } \\
\text { environments }\end{array}$ & $\begin{array}{l}\text { Promotes } \\
\text { regeneration and } \\
\text { appropriate use of } \\
\text { land, buildings and } \\
\text { infrastructure } \\
\text { - Promotes the use of } \\
\text { both brownfield and } \\
\text { Greenfields } \\
\text { Conserve important } \\
\text { environment, } \\
\text { historical and cultural } \\
\text { assets } \\
\text { Protects and enhances } \\
\text { areas for recreation } \\
\text { and natural heritage. } \\
\text { Promotes access to all } \\
\text { mode of transport } \\
\text { Encourages energy } \\
\text { efficiency in the } \\
\text { layoutand design of } \\
\text { development }\end{array}$ \\
\hline
\end{tabular}


Virtually all buildings at Mepe were not erected in compliance with fire and building safety codes as noted in the work of [4]. In their work on unauthorised structures in high-rise high-density environment, they suggested that unauthorised buildings tended to create both hygiene and safety related problems. Thus, such buildings may obstruct fire escape routes and lead to high casualties in case of fire. More so, the questionable structural integrity of such buildings poses a risk to humanity. [5], in their study on contemporary principles and practice for local planning, reported that SP occurred at region, metropolitan, district, corridor, street and block levels. This scenario is non-existent in most major towns and cities in Ghana. The non-existence of SP is due to several challenges. The most intractable of these is the historical problems of family land ownership managed by clan heads. While Western systems of land ownership under individual freehold titles were introduced in the Eastern and Southern parts of Africa during colonial rule, land ownership in Ghana and many parts of West Africa largely remained under customary jurisdiction. However, the long-established lineage and clan land ownership meant that there was no tradition of systematic land allocation for public infrastructure development such as vehicular access roads to all residential areas. Consequently, early dwellings were clustered or concentrated densely on family land. Even when land disputes and litigation forced clans to start selling land to individuals to raise money, landowners made no provisions for green spaces, gardens, public parks to socialize. [6] studied the principles and guidelines for layout planning in urban places. They argued that the design and layout of local areas were necessary for easy movement, safety and pedestrian convenience. Individual landowners exacerbated the problem.

As a background, this study discusses the early settlement history, land ownership and custodian issues, geography and natural resources, economic activities, politics and planning regulations, types of buildings and materials as well as education and training to increase the understanding of the current building construction landscape at Mepe. This is linked to existing studies on SP in the context of Ghana. The paper uncovered some factors that influenced the non-compliance and unplanned spatial development in many parts of the country using Mepe township as a case study. Prominent among these factors are poor quality apprenticeship training programmes, the exorbitant cost of site layout and building plans as well as the inability of land custodians to demarcate site boundaries with well written mathematical descriptions based on coordinate systems. Other factors include the failure of the district assemblies and town country planning departments to develop zoning schemes and general spatial plans for most towns in the country. The inability of prospective homeowners to obtain planning permits from the mandated authorities for SP decision also contributes to the unplanned nature of most of the urban centres in Ghana.

\section{The Global and Local Perspectives of Spatial Planning Research}

There is no universally accepted definition of SP. However, in recent times, SP has attracted considerable global attention. For instance, [7] examined the global perspective 
of urban geography. He reported that increasing competition for space among human activities was the motivating factor for land-use planning. He argued further that the results of the 1947 United Kingdom planning system show that proper land use and planning achieved the twin goals of curbing spatial sprawl and agricultural land protection. In a study by [8] on the effects of land use regulations on property values in Oregon, USA, they argued that land use regulations contribute to community health, safety, and welfare. According to the study, strict land-use regulation enforcement meant harmonious land development, functional housing efficiency and improved neighbourhood characteristics [8]. In the view of the United Nations Economic Commission for Europe (UNECE) [9], SP means the promotion of sustainability, economic, social and environmental quality in urban and rural areas (see Table 1). A case study research conducted by [10] on the factors influencing town planning and urban housing development in Kuala Lumpuralso revealed that efficient planning control was essential in ensuring orderly and sustainable development as well as improving housing and neighbourhood environments. According to the researcher, the attainment of adequate shelter, preservation of property values and the enhancement of individual housing experience depend on efficient planning. Similarly, an examination of recent trends in land use transformation in the peri-urban areas of Dar es Salaamalso revealed that unregulated land development had given rise to many complex and organic urban structures which predominantly expanded horizontally [11]. As a result, land-use did not conform to planning norms and standards for zoning and population density distribution.

In the context of Ghana, the publication of the Town and Country Planning Ordinance of 1945 by the colonial administration launched SP discourse in Ghana. A review of SP and urban fragmentation was conducted in Accra. It was noted that, beyond the planned areas where the colonial authorities and expatriate lived and worked, the rest of Accra's development was in a disorderly manner [12]. Lack of planning created fragmented structures and totally uncontrolled urban development. Similarly, it was argued that SP in colonial Ghana occurred only where the colonial administrators and expatriates lived [13]. [13] further noted that an uncontrolled urban development in downtown Accra was replicated in most peri-urban areas due to the lack of planning and development controls. The above assertion was confirmed in a review of building materials and construction practices in Accra [14]. These researchers found that the materials used in building houses in the well-planned areas included concrete blocks and iron or aluminium roofing sheets. However, the unplanned areas were often littered with masses of thatched buildings arranged in a haphazard manner. Narrow and crooked streets separated these areas. They noted that, in the central business district (CBD) of Accra, zoning and building codes were strictly enforced to maintain an orderly European character and ambience. Land-use planning was achieved by a deliberate separation of expatriate residential areas from native settlements because the latter was perceived as unsanitary. Spatial segregation is especially evident in the major cities of Accra, Kumasi, Cape Coast, Sekondi-Takoradi and other towns where the colonial administrators lived and worked. However, [15] also attributed the beautiful spatial and 
physical development of Wa Township for instance as being influenced by the strict enforcement of the Town and Country Planning Ordinance of 1945. They concluded that, in Wa and other main towns in the country, spaces left in-between buildings were wider enough to provide vehicular access when necessary. Again, SP was more efficient in the well-planned areas than in the overcrowded and spontaneously developed sections of the municipality [16].

In a similar study [17] investigated the growth and development of Kumasi. It was concluded that Kumasi and its surrounding towns are growing rapidly. Urban planning authorities had no time to plan for such town's growth and development. In a follow-up study, [18] reported that many Ghanaian towns were overcrowded with cluttered houses in unsanitary and poor environmental conditions. However, the study noted that the port city of Tema and Akosombo were the first well planned post-independent towns in the country. These cities had well laid out roads, planned neighbourhoods and communities, schools, commercial areas, sewer lines and telecommunication networks. Other well-planned towns included 52 communities built for people displaced by the rising waters of the Volta Lake. The successful planning of these communities showed the country's capacity for creating livable residential areas through systematic and strategic SP [17]. In another study, [19] explored the determinants of low land use planning regulations compliance in Ghana. They found that despite the existence of an adequate framework for land use regulations in the country, planning authorities showed limited interest or lack the capacity for planning regulations enforcement. In that same year, another study by [20] investigated the threats and opportunities for urban and periurban agriculture land use in Tamale. The researchers established that SP in Ghana was typically done at the local level with a focus on urban land-use forms and infrastructural development. In their opinion, little attention was given to livelihood issues thereby creating stress and uncertainties in peri-urban areas where competition for space was the greatest.

In exploring SP within the context of Ghana's social and economic transformation, it was concluded that limited SP by the colonial administration resulted in an imbalanced social and economic development [21]. However, attempts by post-1957 independence governments to improve the situation were plagued with land-use disorder, uncontrolled urban sprawl, inadequate infrastructure, waste management challenges, poorservice delivery and livelihood insecurities [22]. It is on the above premise that the Ghana National Spatial Development Framework 2015-2035 Volume II [7], observed that SP was critical for delivering economic, social and environmental benefits. This national policy framework aims to create a more stable and predictable conditions for investment and community development. The United Nations Economic Commission for Europe and Ghana National Spatial Development Framework positioned the benefits of SP under the three sustainability dimensions of economic, social and environmental benefits as shown in Table 1 .

\section{A Descriptive and Situational Analysis of the Case Study Area}

The town under study is located on the lower Volta River, north of latitude $60^{\circ} \mathrm{N}$ and 
midway between longitude $0^{\circ} \mathrm{E}$ and $10^{\circ} \mathrm{E}$ in the south-east of Ghana. Mepe in Figure 1 is a scenic rural and agricultural community made up of many villages that include Ahumakope, Amekorkope, Boklotorvui, Dadome, Degorme, Dekpo, Fakpoe, Husikope, Mepekope, Nuwloe, Sayikope, Titikope and Zadola with a combined population of nearly 15,000 residents [23]. However, the study focused on houses chosen at random from the incremental house building activities of residents in the town.

\section{Research Methods}

The paper adopted a mixed method research approach to gather the research data through different instruments. Snowball non-probability sampling technique was used to identify 100 local artisans who were members of the Mepe Association of Building Artisans (MABA). Questionnaires were administered to these respondents followed by structured interviews with five (5) Mepe elders who lived in the town continuously for over 65 years. The research instruments compose of four sections. Section A consists of five open-ended questions about those surveyed background. Section B consists of five opened-ended questions about respondent's artisanal training records. Section C consists of four open-ended questions concerning the occupational longevity and two other closed-ended questions, while Section D also contains two closed-ended and eight open-ended questions about land ownership and custodian issues. A smart phone was used to capture the illustrative materials, while the secondary data were extracted from academic publications, district administrative records and national government published documents.

\section{The Research Results and Discussion}

The results of the paper were analyzed in two strands as explained in the method research approach. These are further elaborated below.

\subsection{The Qualitative Strand of the Research Results and Discussion}

The qualitative interviews conducted with the elders of the town were analyzed under

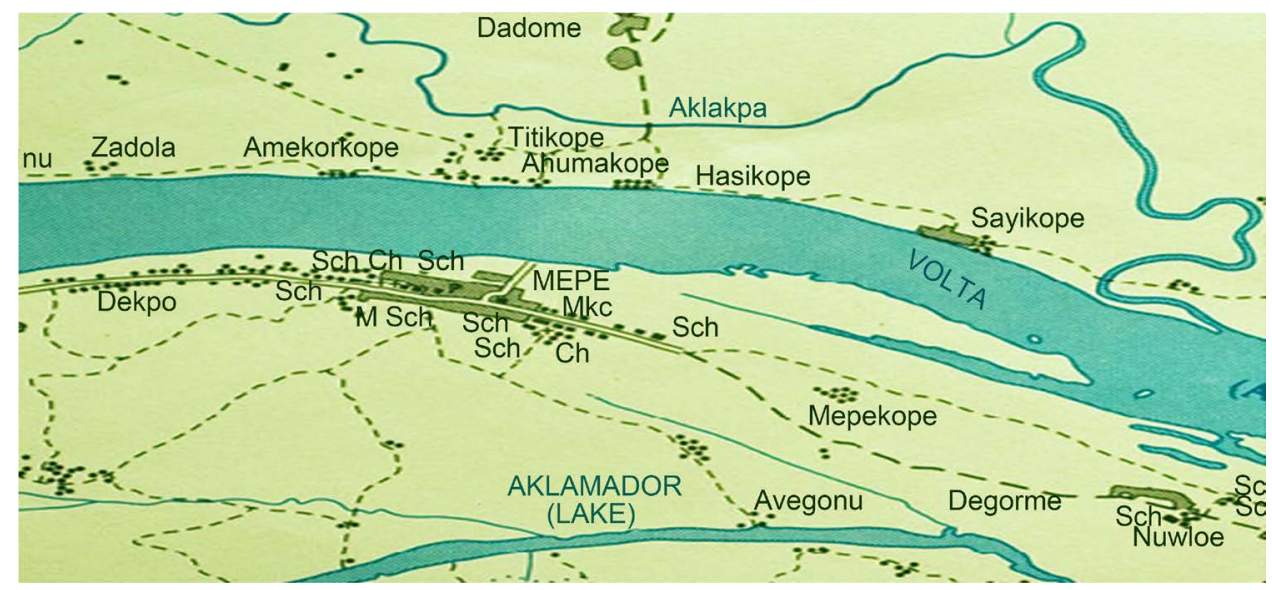

Figure 1. Map of Mepe and its Environs, source [24]. 
seven thematic perspectives. These are; the historical antecedents of Mepe early settlement, land ownership and custodian issues, the geographical and natural resource base, the local economic activities, the politics and planning regulations regime, the typology of buildings and construction materials and the education and training needs of artisans in the town. The themes are discussed, and the profiles of the participants listed in Table 2 below.

\subsubsection{The Historical Antecedents of Mepe Early Settlement Perspective} In the view of (Interv, 4) Mepe is divided into five divisional clans, namely: Akorvie, Dzagbaku, Dzoxornu (Adzigo), Gbanvie and Sevie. According to (Interv, 3), “Mepe was founded in the 17th century by two hunters known as Togbe Nala of Dzoxornu and Togbe Akabu of Dzagbaku". Nala led a group of migrants from Ketu, Benin, while Akabu's group escaped from the wicked rule of King Agorkolie of Notsie in Togo. The Sevies and Gbanvies were part of this group, while the Akorvies escaped from the Ashanti Empire Warfrom 1824 to 1901. The followers of Nala and Akabu reached a couple of months apart and built their dwellings near and around their early leaders' houses (Interv, 3). The migrants of the other three clans built similar dwellings on land generously given to them as community properties by Nala and Akabu (Interv, 2).

\subsubsection{Land Ownership and Custodian Perspective}

Until 1964, speculative or non-speculative ownership of land in perpetuity was non-existent at Mepe and other parts of Ghana. However, after 1964, an enormous inter-clan court case between the Dzagbaku Afevieme (lower gate) and Afegame (upper gate) forced both gates to start selling or leasing lands to individual buyers or lessees to raise money to pay the legal fees being charged. A residential land of $14.40 \times 14.40 \mathrm{~m}$ $(48 \times 48 \mathrm{ft})$ size could be sold between USD 0.005 to USD 0.007 , and land of $21.60 \times$ $21.60 \mathrm{~m}(72 \mathrm{ft} \times 72 \mathrm{ft})$ size was also leased for USD 1.09 at current Bank of Ghana exchange rate of USD 1.00 to GH\$3.96. Today, land sizes vary from $70 \times 100 \mathrm{ft}(21.60 \times$ $30.00 \mathrm{~m})$ to $100 \mathrm{ft} \times 100 \mathrm{ft}(30.00 \times 30.00 \mathrm{~m})$ and could as well cost between USD 904.55 and USD 1338.74 respectively. Interv, (3) recalled that "Initially, land was sold or leased without indenture agreements or layout plans". However, today, no land transaction is executed without these legal documents. In his view, the current modern practice of land documentation processes is very cumbersome and difficult.

Table 2. Profile of participants.

\begin{tabular}{ccccc}
\hline Nr & Gender & Age & Participant background & Code-named \\
\hline 1 & Male & 67 & Clan head & Interv, 1 \\
2 & Male & 68 & Sec. to Nala Land Custodians & Interv, 2 \\
3 & Male & 66 & Head of Akabu Family & Interv, 3 \\
4 & Male & 69 & Sub-divisional chief & Interv, 4 \\
5 & Male & 69 & Master craftsman & Interv, 5 \\
\hline
\end{tabular}




\subsubsection{The Geographical and Natural Resource Base Perspective}

It emerged from the interviews that geographically, the town covers an area of approximately $26.88 \mathrm{sqm}$. $\mathrm{km}$. It is located on both sides of the banks of the lower VoltaRiver and within the proximity of the river's tributaries like Abu, Aklakpa and Awutor as well as Lake Gbortoe. This means that "Mepe is endowed with many fish resources that include Centropomidae, Characidae, Cichlidae, claroteidae, Cyprinidae, Osteoglossidae and superabundance of oysters" (Interv, 2). Interv, (3) on the other hand recounted that "centuries of annual flooding and shifting river courses have spread immense oyster shell deposits all over Mepe and its environs in solitary and continuous heaps covered with soil and vegetation". These shells are now being mined and used as essential coarse aggregates in cement concrete for various types of construction works. Mahogany and similar trees are harvested from the relatively flat and undulating savanna surroundings with the scattered forest for construction purposes. Quoting (interval, 5), "clayey soil is plentifully available both along the river banks and inland". Annual temperatures of $27^{\circ} \mathrm{C}$ to $33^{\circ} \mathrm{C}$ are usually recorded during March to November and $28^{\circ} \mathrm{C}$ to $34^{\circ} \mathrm{C}$ from December and February each year.

Regarding road networks, two main roads run through the town. While one of them links the international highway from Accra-Lome in Togo at Sege in the west and Vume on the east, the other one serves as a link road connecting the main road from Salem Junction to Tegola and Dzoxornu Torkor. There is hardly any space in-between most of the houses. For instance, space in-between the houses on both sides of the alley that stretches from Salem to Tegola ranges from $0.6 \mathrm{~m}$, to $1.0 \mathrm{~m}$ with the widest being $2.08 \mathrm{~m}$. Of the 5896 houses counted, one block away from this alley, only three, two 4-storey buildings and one single-storey building were built with a permit from the North Tongu District Assembly (NTDA) planning authorities. The lack of adequate and well-planned access roads and alleys coupled with the narrow nature of those available made it difficult for service companies such as the electricity company of Ghana (ECG) and community water and sanitation agency to extend their services to clients. This has been demonstrated in Figure 2 and Figure 3 below. The deleterious effect of these unplanned and unattended developments is that no consideration is given to the influence of rain water in case of flooding by these local artisans anytime they are building.

\subsubsection{The Local Economic Activities Perspective}

Before the construction of the Akosombo and Akuse dams in 1965 and 1982 respectively, the local economy of Mepe's revolved primarily around oyster harvesting, fishing and farming activities. Oyster harvesting according to (Interv, 3) was lucrative particularly for most women who later owned many properties in the town. However, (Interv, 2) added that fishing also contributed immensely to the economic well-being of the people but not to the extent of Oyster harvesting. Although, vegetable farming was also a full-time living occupation for most men and women, the construction of the dams destroyed the prospects of the above local economic activities of the people in the area. A case in point is the stoppage of floods resulting from the slow pace of the river 


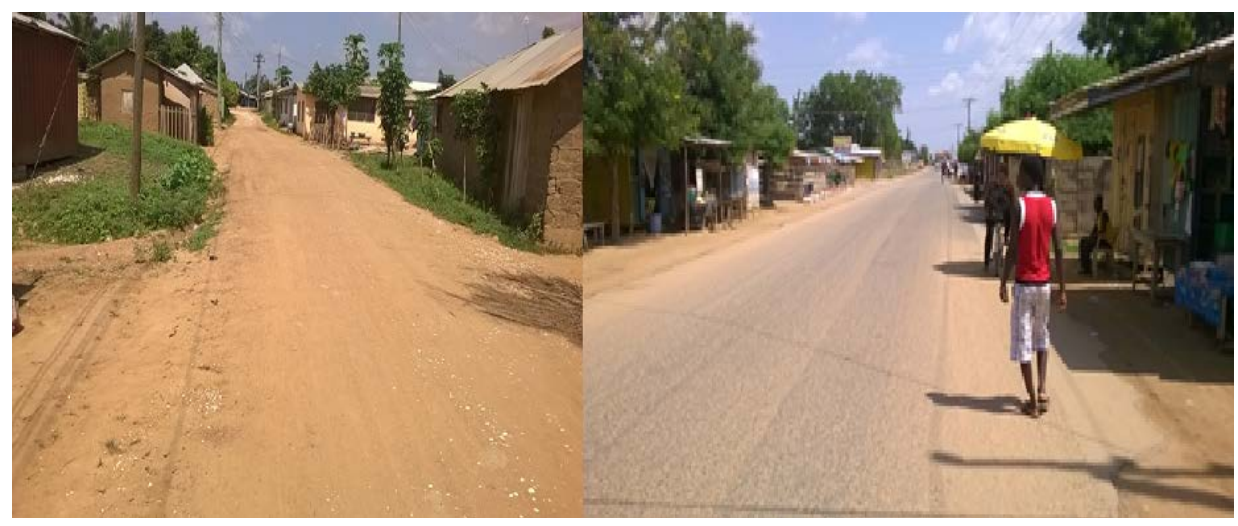

Figure 2. The two main roadways in Mepe.

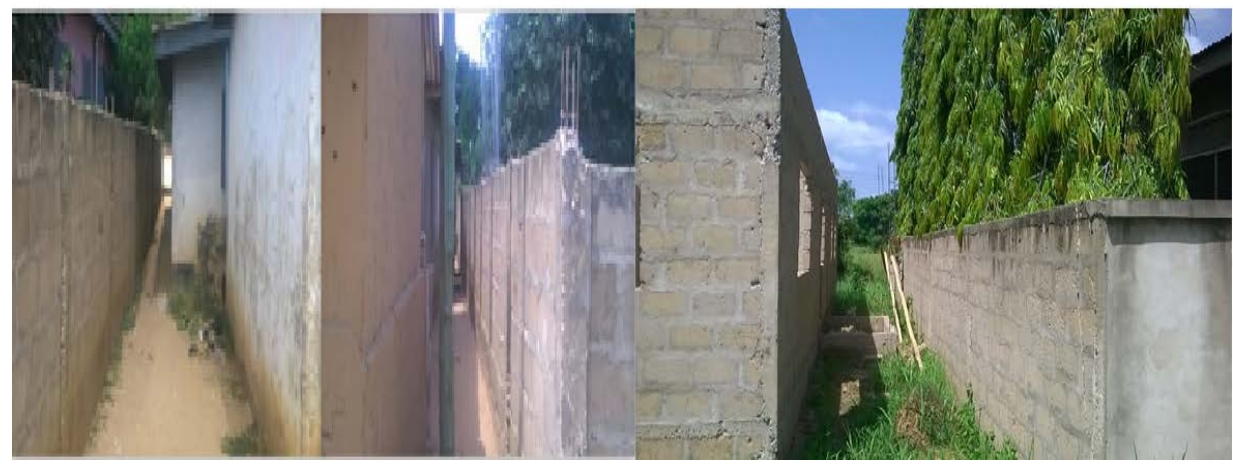

Figure 3. The narrow spaces in-between new residential buildings.

currents from the dam. It breeds riverbed weeds over the oysters and farmlands seized to be annually replenished and invigorated by alluvial soils. However, the establishment of the Mepe rural bank in 1991 revived some of the economic activities as can be seen in Figure 4. Accessible and affordable loans spawned flourishing cottage industries such as concreteblock making, food processing, flour mills, blacksmithing, pottery and garment making. The proceeds from these ventures instigated property development boom in and around the catchment area. The erection of a mobile-phone tower in the west end of the town in 2008 further boosted wealth creation among the people in the town. While business operators could check industry and market trends; local artisans easily stayed in touch with their clients and colleagues. These economic drivers led to the expansion of Mepe's housing construction sector during the last two decades.

\subsubsection{The Politics and Planning Regulations Perspective}

The Mepe Traditional Council (MTC) and the Mepe Development Association (MDA) are traditionally responsible for land and building disputes resolution. The MTC, which comprises of 5 divisional-clans' chiefs and five sub-divisional clan chiefs are headed by Togbe Anipati, the paramount chief. The council used to derive its powers from sections 42 and 43 of Ghana chieftaincy Act [25], as amended by Chieftaincy (Amendment) Decree, 1973 (NRCD 166), Chieftaincy (Amendment) (No. 2) Decree, 1973 
(NRCD 226), chieftaincy (amendment) law of 1982 (PNDCL 25) and chieftaincy (amendment) law of 1993 (PNDCL 307). The MDA also doubled as the MTC's socioeconomic development agency and is guided by the Town and Country Planning Ordinance, Cap 84 of 1945 . They are also guided by all the related technical memoranda for zoning and SP in Ghana prior to the drafting of the country's first building code and enactment of the National Building Regulations (LI 630) in 1988 and 1996 respectively. Currently, at the district assembly level, these regulations are being enforced by the NTDA.

\subsubsection{The Typology of Buildings and Construction Materials Perspective}

The early houses in Mepe were built with mud (Atakpame) and wattle and daub (Kafui). They were roofed with dried thatch or palm fronds. The floors were made of clay while the doors were fabricated with palm fronds or straw mats with windows measuring $2 \mathrm{ft} \times 2 \mathrm{ft}$. As a result of the aforementioned economic fortunes, bricks and concrete blocks were introduced alongside clay roofing tiles, aluzinc roofing sheets, asbestos, shingles and concrete roofing tiles. The floors of these modern buildings are finished in ceramic/porcelain tiles with walls of cement mortar plastering and acrylic paint. Figure 5 depicts two distinct buildings of modern and early days of Mepe, all constructed by the local artisans.

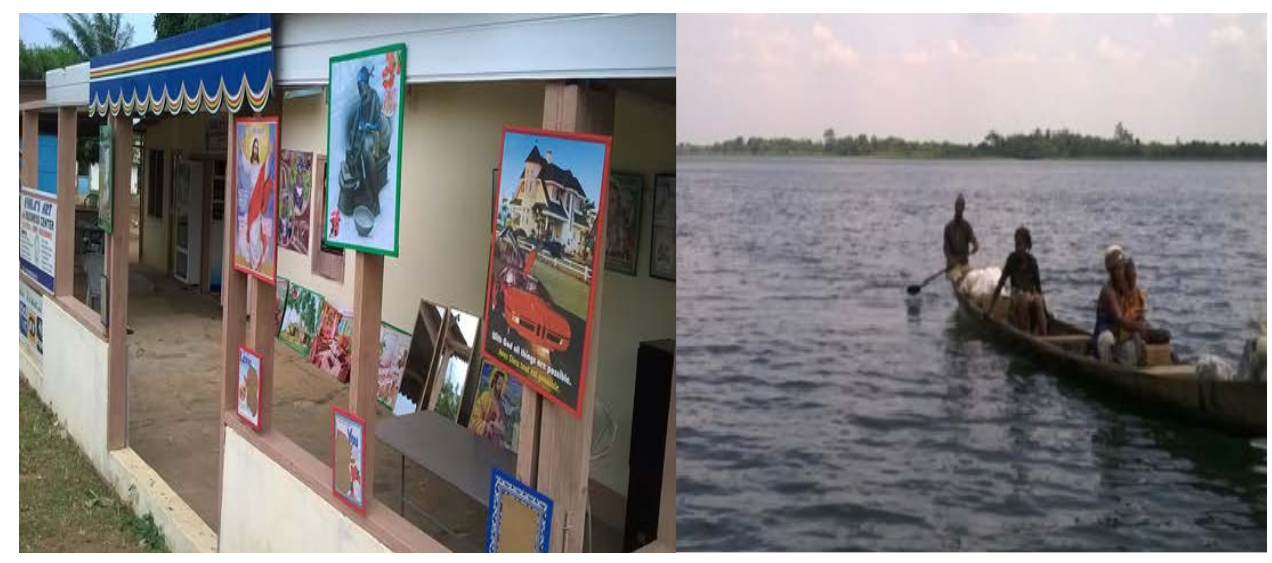

Figure 4. Some economic activities taking place in the town.

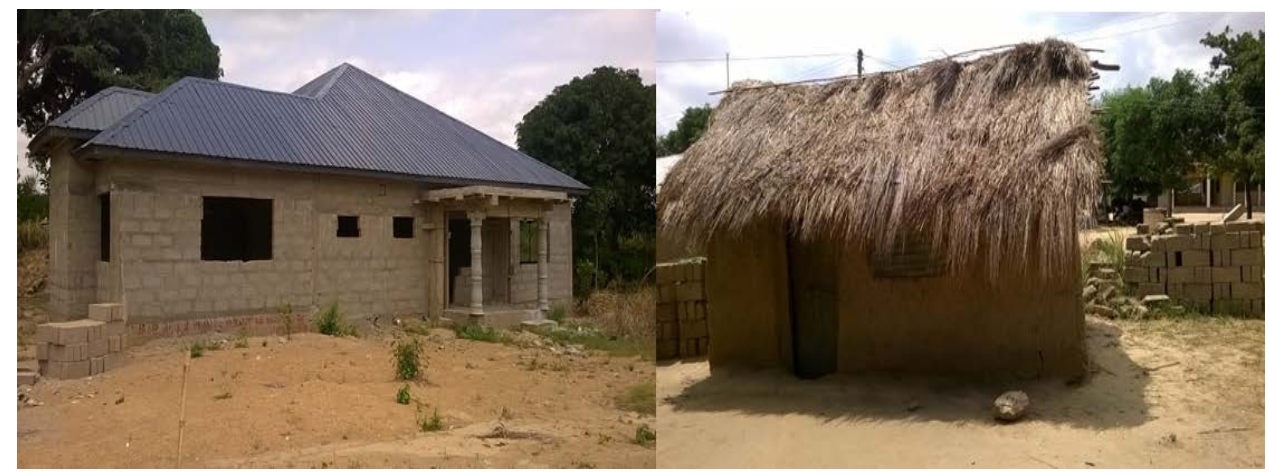

Figure 5. Modern day sandcrete block and olden day dried thatch buildings. 


\subsubsection{The Education and Training Need Perspective of Artisans}

Originally, skills training at Mepe were conducted through informal-apprenticeship systems based on verbal agreements between a master craftsmen and an apprentice. By 1898, the Basel mission started formalizing the training process of their local faithful with the opening of the first primary school at Mepe. Shortly afterwards in 1930, the Roman Catholic mission also established the Roman Catholic primary school. Today, Mepe has eight basic schools, four primary and four junior high schools. In 1980, St. Kizito Technical Institute was founded to train trade artisans. St Kizito has since been converted to a senior secondary technical school with more emphasis on accounting and arts subjects with little attention given to technical and vocational subjects.

\subsection{The Quantitative Strand of the Research Results and Discussions}

At the end of the data collection period, 89 completed questionnaires were realized out of the 100 that were distributed, yielding a response rate of $89 \%$. Of these, almost $10 \% \mathrm{n}$ (9) contained no information and were not included in the analysis. All the respondents were men, comprising of masons $53 \% \mathrm{n}(42)$, carpenters $25 \% \mathrm{n}(20)$ steel benders $19 \%$ $\mathrm{n}(15)$ plumbers $8 \% \mathrm{n}(6)$ and electricians $6 \% \mathrm{n}$ (5). In earlier studies, [26] reported that men were preferred over women in the American construction industry. Similar findings were reported in the UK and Kenyan construction industries respectively [27] [28]. The respondents were asked about their ages. As a labour intensive industry that requires physical strength, age is a critical variable affecting construction trades. The respondents' ages ranged from 18 to 65 years with the majority being in the 26 year's brackets $44 \% \mathrm{n}$ (35). 19\% n (15) of them were between 40 and 50 years, while $18 \% \mathrm{n}$ (14) were between 20 to 30 years. Again, almost 13\% n (10) of the respondents were in the 50 to 60 years age bracket while another $8 \%$ n (6) were over 60 years of age. The respondents were also asked about their educational qualifications and the results show that, $42 \% \mathrm{n}$ (34) of them completed junior high and middle schools. About $40 \% \mathrm{n}$ (32) had attained vocational, and technical education while $18 \% \mathrm{n}$ (14) completed senior high school as shown in Figure 6. This finding coincides with the results of [29] who reported in a similar study that $68 \%$ of artisans in Ghana construction sector had formal education up to Junior high school.

Regarding artisanal training, 54\% n (43) of the respondents reported to have acquired their skills through trade apprenticeship while $46 \% \mathrm{n}$ (37) acquired their training

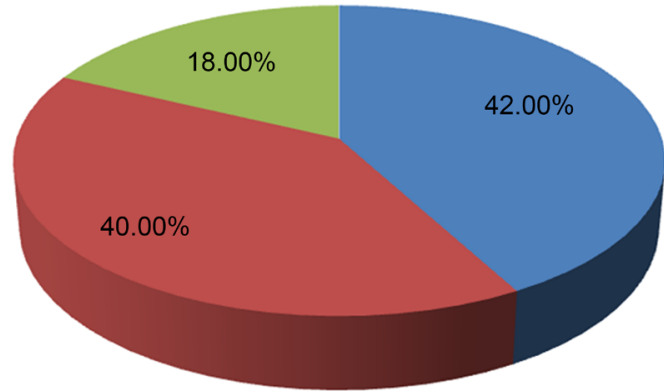

JuniorHigh/Middle School

Vocational/Technica

Education

Senior High School

Figure 6. Local artisans' educational background. 
through formal training such as vocational and technical schools. The above is also consistent with [30] who attributed poor construction workmanship in Ghana to the pervasiveness of apprenticeship training where master craftsmen transfer knowledge informally to apprentices in the country. These informal arrangements frequently resulted in the transfer of wrong or inadequate skills to apprentices. For instance, Figure 7 shows two pictures of the work of an apprentice (left) and that of his master (right). The bricks joints on the apprentice work were not laid to meet at a perfect $90^{\circ}$ angle as compared to that of the master who incorporated aesthetically drawn mortar joints between each brick. On the longevity of apprenticeship training programs, almost $41 \%$ n (33) of respondents spent two years in training, 28\% n (22) spent between 2 to 3 years, while $31 \% \mathrm{n}$ (25) spent 3 to 4 years in training. According to (interval, 4) who was a master craftsman in charge of 8 apprentices stated that apprenticeship programs typically must last between 4 to 6 years in extreme cases. However, most Ghanaian artisans' primary focus is often on the "monetary gains which lead to early exits immediately they can lay one or two cement blocks" (interval, 4). They usually start to advertise themselves as professional artisans.

Regarding working experience, the respondents were also asked to identify their occupational longevity. The results show that $13 \% \mathrm{n}(10)$ of them had between 1 to 5 years of experience, $23 \% \mathrm{n}$ (18) 5 to 10 years, $28 \% \mathrm{n}$ (22) had 10 to 15 years, whilst $38 \% \mathrm{n}$ (30) had 15+ years of experience in the building construction sector. About 66\% n (53) were certified by the National Vocational Training Institute (NVTI) before they started practicing as artisans while $34 \% \mathrm{n}$ (27) were not. Some of the reasons for the non-certification were due to the instability or relocation of their trade masters due to the urban mobility in the country. Other reasons include the death of their trade masters, and some were not given the opportunity to write the trade certification examinations. Respondents were also asked about whether they normally receive building site plans from clients before starting work. The results show that $41 \% \mathrm{n}$ (33) asked clients for site plans to enable them locate and set-out buildings appropriately, while $59 \% \mathrm{n}$ (47) do not. According to one respondent, "clients complained of the high cost of site and building plans and instead of asking architects, they often turned to us for building plans" (interval, 5). On the use of proper building identification tools to identify their clients building plots demarcations, 33\% n (26) used site layout or plans to locate clients' building site, while $68 \% \mathrm{n}$ (54) do not. According to one of the respondents, building-site identification became a huge problem because land custodians do not physically demarcate boundaries on the ground with concrete pillars or by written mathematical descriptions based on coordinate systems. It is, therefore, being suggested that a boundary demarcation of residential lands, roadways and alleys by concrete posts as against what is shown in Figure 8 below as the convention.

When respondents were asked about their awareness of building permit requirements by the district assembly, 71\% n (57) stated they were aware and understood the building permit regulations, while $29 \% \mathrm{n}$ (23) were unaware of this vital SP requirements. The above finding contradicts [31], who reported that artisans were ignorant of 


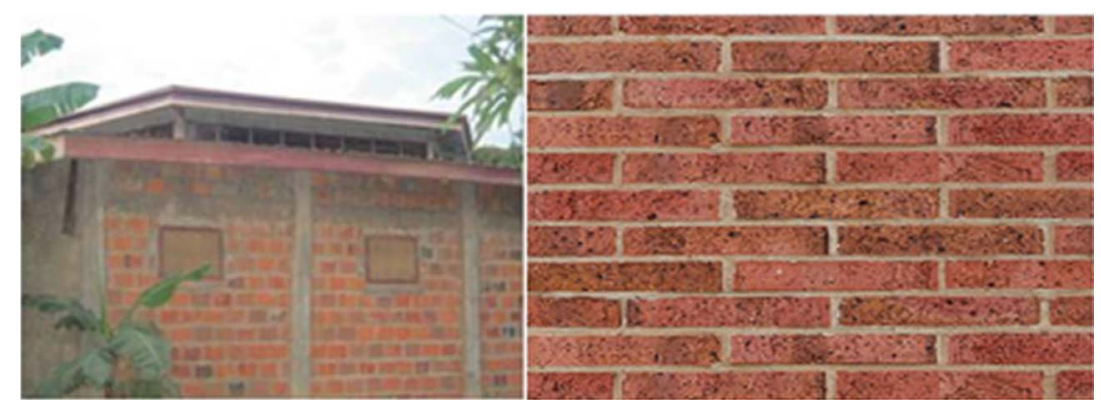

Figure 7. Examples of a poor and good workmanship. Source: Field study picture repository, 2016.

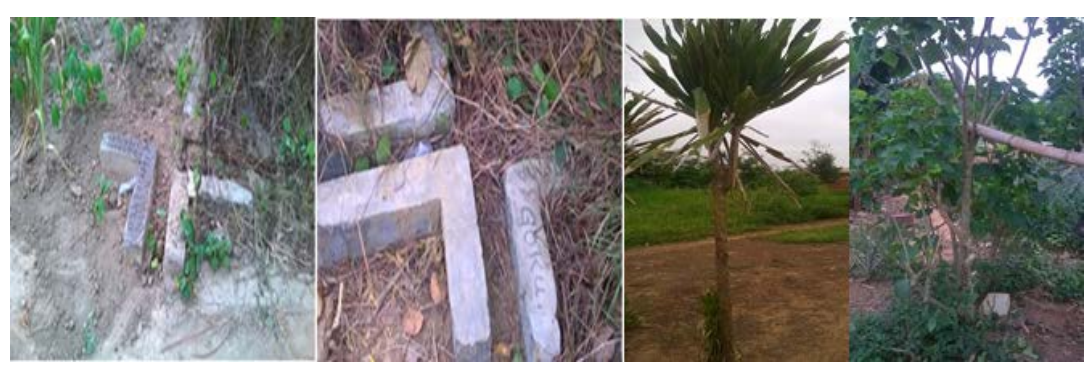

Figure 8. Examples of modern land boundary markers. Source: Field study, 2016.

building permit regulations in a land-use implementation study of Port Harcourt Metropolis in Nigeria. However, almost $14 \%$ n (11) relied on building permit documents obtained from NTDA for SP decision makings, 25\% n (20) used their personal experience, while $61 \% \mathrm{n}$ (49) followed clients' instructions. Although these artisans were aware of the requirements and importance of building permits, the majority were not interested in complying with it due to lack of monitoring and enforcement by the district assembly. In the opinion of (Interv, 2) he noted that construction of unauthorized buildings was due to the high cost of building plans and the unwaton delays in getting permits approvals from the authorities in charge. These results coincide with [32] and [33]. They suggested that the long delays in obtaining building permits were a huge deterrent in complying with SP and other district assembly bylaws concerning siting buildings in Kumasi and Sekondi-Takoradi regions of Ghana. Interv, 5, stated that most of the property developers were always willing to obtain building permits but were deterred by bureaucratic bottlenecks at the district assembly. As a result, property owners dreaded the red tape of obtaining such permits than to proceed with the development. A similar outcome was reported in Kumasi where almost $80 \%$ of the houses built were without the appropriate building permits from the town and country planning department of the Kumasi Metropolitan Assembly (KMA) [34].

\section{The Role of Local Artisans in SP in Ghana}

SP has been defined in different ways by various authorities. However, regarding space and infrastructure planning, local artisans can play a significant role in ensuring sanity in the built environment within the different districts and localities. From the above 
findings, it is clear that local artisans can help in the effective implementation of SP framework policies by the district assemblies. Most of these artisans have first and second cycle education where settlement planning is studied under social studies. The various district assemblies can complement this basic knowledge of artisans by training them to liaise properly with land custodians in planning land sales and development. It is evident from the above findings that, there is a high dominance of informally trained artisans which constitute an informal labour force in the construction sector. This has resulted in the construction of unauthorized buildings and structures as well as the disregard for the need for proper layouts and provision of suitable housing infrastructure. These have often led to perennial flooding in most of Ghanaian towns and cities. This paper further argues that the local authorities at the various district assemblies must be ready to work with informality. The assemblies should also put measures in place to integrate such practice as reported in this paper in their mainstream local policies on SP. This would involve finding ways to engage pro-actively with local artisans and build on the contribution of such informal processes, actors and resources to harness the towns and cities development. The tradition of disregarding such informal contributions and attempting to control them through regulation at all costs must be given another look. It is also the view of this paper that planning based on formal processes alone in the context of an emerging economy such as Ghana is in general not good at dealing with informality. In most Ghanaian localities, artisans are often in close contact with land custodians and prospective homeowners. With adequate training and knowledge on the national building regulations and SP frameworks, they will serve as trusted resource persons or local advisors to land custodians and prospective homeowners who do not have much knowledge of building regulations.

The lack of knowledge of some of the artisans as discovered in this paper has accounted for the unauthorized siting of buildings on waterways and areas meant for other significant use. This is because of ignorance of both local artisans and prospective homeowners on planning schemes and building regulations at the various local assemblies. There is the need to intensify education on some of the provisions such as the local government Act 462, Sections 51 and 52. This act stipulates that any unauthorized developments which include buildings on any public land could be stopped or demolished without notice and the developers surcharged with the cost of demolition. The above pointed to a general lack of monitoring on SP development which has been a major challenge. Therefore, educating local artisans would complement city authorities' efforts in the implementation of the above Act. Again, since both financial and logistics have being another setback to the effective implementation of SP, local artisans can be engaged in monitoring SP implementation frameworks. This is because their activities have come to stay and are already established in the various communities. It would be very easy for them to monitor whatever that is going on in their respective jurisdictions and report to the MMDAs. Collaboration with the informal sector labour workforce can also strengthen the legitimacy of planning and regulatory systems that can progressively achieve adequate standards and regulations in the built environment in Ghana. 


\section{The Research Implications}

There is the need for a paradigm shift from a reactive planning approach to a more pragmatic and proactive approach to urban planning in Ghana. The participation or inclusion of artisans in planning would set the tone for a different approach from the rigidly formalized planning to a comprehensive planning that would involve the informal sector. Thus, participatory planning will empower local communities that would result in better design outcomes. These results would lead to a more responsive spatial development that will meet the diverse needs of the different urban segments of the population in the country. The practical implication of involving artisans in SP is that, their inclusion in the planning, design and implementation of spatial programmes would be very effective at the local levels. This would help reduce the sprawling of slums and thereby reduce environmental hazards such as flooding among others. Extant literature has indicated that political influence has been one of the factors affecting SP in Ghana (cf. [35]). This paper is of the view that local artisans may not be all that "politically powerful". Therefore, involving them in SP at the grass root level will help dilute the effect of political interferences. The social dimension of the findings in this paper is that by involving artisans in SP would help protect and improve the social status of our towns and cities. The social consequences of slums and their formation such as flooding, lack of social amenities and sanitation problems in our major cities and towns in Ghana would also be reduced to the barest minimum if not solved entirely. For economic activities to thrive well in any given environment there is the need for a well-planned layout of that environment.

\section{Conclusions}

This paper discovered some of the contributing factors that influenced the non-compliance and unplanned spatial development in many parts of the country by using Mepe town as a case study. Prominent among these factors are poor quality apprenticeship training programmes, the exorbitant cost of site layout and building plans. The inability of land custodians to demarcate site boundaries with well written mathematical descriptions based on coordinate systems is another factor. Other factors include the failure of the district assemblies and town country planning department to develop zoning schemes and general spatial plans for most towns in the country. Lack of zoning schemes made it difficult to differentiate between residential and industrial lands, markets, schools, public playgrounds, roadways and service lines. The inability of prospective homeowners to comply with planning regulations by obtaining planning permits from the mandated authorities for SP decision also contributes to the unplanned nature of most urban centres in Ghana.

Given the above findings, this paper argued that the government should regularize informal apprenticeship training programmes. This can be done by providing funding of the Opportunity Industrialization Center (OIC) of Ghana to extend its training programmes to most towns including Mepe. The government should also provide the necessary funding and logistics to all the town and country planning departments in the 
district assemblies to survey and map out lands for integration into national planning regulation documents. The operationalization of the Ghana National Spatial Development Framework 2015-2035 Volume II can be effective in training local artisan on its use and part of its implementation process. The various district assemblies should also embark on public education initiatives to educate the populace about the socio-economic importance of SP regulations compliance. Further research is also necessary to determine the success of these and related initiatives.

\section{References}

[1] Smith, C. and Levermore, G. (2008) Designing Urban Spaces and Buildings to Improve Sustainability and Quality of Life in a Warmer World. Energy Policy, 36, 4558-4562. http://dx.doi.org/10.1016/j.enpol.2008.09.011

[2] GNSDF (2015) Ghana National Spatial Development Framework 2015-2035 Volume II: Overall Spatial Development Strategy.

[3] Grubler, A., Bai, X., Buettner, T., Dhakal, S., Fisk, D., Ichinose, T., Keirstead, J., Sammer, G., Satterthwaite, D., Schulz, N., Shah, N., Steinberger, J. and Weisz, H. (2012) Urban Energy Systems. In: Global Energy Assessment. Toward a Sustainable Future, Cambridge University Press, Cambridge and New York and the International Institute for Applied Systems Analysis, Laxenburg, 1307-1400. http://dx.doi.org/10.1017/CBO9780511793677.024

[4] Lai, L.W.C. and Ho, D.C.W. (2001) Unauthorised Structures in High-Rise High-Density Environment. Property Management, 19, 112-123. http://dx.doi.org/10.1108/02637470110387830

[5] Hack, G., Birch, E.L., Sedway, P.H. and Silver, M.J., Eds. (2009) Local Planning: Contemporary Principles and Practice. ICMA (An ICMA Green Book), Washington DC, 165-172.

[6] Behrens, R.B. and Watson, V. (1996) Making Urban Places: Principles and Guidelines for Layout Planning. Juta Academic, Cape Town.

[7] UNCEC (2008) Spatial Planning: Key Instrument for Development and Effective Governance. http://www.unece.org/fileadmin/DAM/hlm/documents/Publications/spatial_planninge.pdf

[8] Yang, G., Bowling, L.C., Cherkauer, K.A., Pijanowski, B.C. and Niyogi, D. (2010) Hydroclimatic Response of Watersheds to Urban Intensity: An Observational and Modeling-Based Analysis for the White River Basin, Indiana. Journal of Hydrometeorology, 11, 122-138. http://dx.doi.org/10.1175/2009JHM1143.1

[9] Pacione, M. (2009) Urban Geography: A Global Perspective. 3rd Edition, Routledge, London.

[10] Jaeger, W.K. (2006) Effects of Land-Use Regulations on Property Values. The. Envtl. L., 36, 105.

[11] Mohd, I., Ahmad, F. and Norazriyati Wan Abd Aziz, W. (2009) Exploiting Town Planning Factors in Land Development: Case Study of Urban Housing in Kuala Lumpur, Malaysia. Journal of Facilities Management, 7, 307-318. http://dx.doi.org/10.1108/14725960910990053

[12] Kombe, W.J. (2005) Land Use Dynamics in Peri-Urban Areas and Their Implications on the Urban Growth and Form: The Case of Dar Es Salaam, Tanzania. Habitat International, 29, 113-135. http://dx.doi.org/10.1016/S0197-3975(03)00076-6

[13] Larbi, W.O. (1996) Spatial Planning and Urban Fragmentation in Accra. Third World Planning Review, 18, 193. http://dx.doi.org/10.3828/twpr.18.2.512j2355x17032m1 
[14] Gough, K.V. and Yankson, P.W. (2000) Land Markets in African Cities: The Case of PeriUrban Accra, Ghana. Urban Studies, 37, 2485-2500. http://dx.doi.org/10.1080/00420980020080651

[15] Grant, R. (2009) Globalising City: The Urban and Economic Transformation of Accra, Ghana. Syracuse University Press, New York.

[16] Ahmed, A. and Dinye, R.D. (2011) Urbanisationand the Challenges of Development Controls in Ghana: A Case Study of Wa Township. Journal of Sustainable Development in Africa, 13, 211-233.

[17] Boamah, N.A., Gyimah, C. and Nelson, J.K.B. (2012) Challenges to the Enforcement of Development Control in the Wa Municipality. Habitat International, 36, 136-142. http://dx.doi.org/10.1016/j.habitatint.2011.06.010

[18] Adarkwa, K.K. (Ed.) (2011) Future of the Tree: Towards Growth and Development of Kumasi.

[19] Adarkwa, K.K. (2013) The Changing Face of Ghanaian Towns. African Review of Economics and Finance, 4, 1-29.

[20] Awuah, K.G.B. and Hammond, F.N. (2014) Determinants of Low Land Use Planning Regulation Compliance Rate in Ghana. Habitat International, 41, 17-23. http://dx.doi.org/10.1016/j.habitatint.2013.06.002

[21] Gyasi, E.A., Fosu, M., Kranjac-Berisavljevic, G., Mensah, A.M., Obeng, F., Yiran, G.A.B. and Fuseini, I. (2014) Building Urban Resilience Assessing Urban and Peri-urban Agriculture in Tamale, Ghana. Springer, Dordrecht, 87-97.

[22] Fuseini, I. and Kemp, J. (2015) A Review of Spatial Planning in Ghana's Socio-Economic Development Trajectory: A Sustainable Development Perspective. Land Use Policy, 47, 309320. http://dx.doi.org/10.1016/j.landusepol.2015.04.020

[23] Awuah, K.G.B., Hammond, F.N., Lamond, J.E. and Booth, C. (2014) Benefits of Urban Land Use Planning In Ghana. Geoforum, 51, 37-46. http://dx.doi.org/10.1016/j.geoforum.2013.09.019

[24] GSS (2014) GLSS 6 Poverty Profile-Ghana Statistical Service. http://www.statsghana.gov.gh/docfiles/glss6/GLSS6_Poverty\%20Profile\%20\%20ghana.pdf

[25] Alohaecowas (2014) Maps. http://www.alohaecowas.com/proposed-site-at-mepedegorme.html

[26] Ghana Chieftaincy Act 1971 (Act 370), as Amended by Chieftaincy (Amendment) Decree, 1973 (NRCD 166), Chieftaincy (Amendment) (No. 2) Decree, 1973 (NRCD 226), Chieftaincy (Amendment) Law, 1982 (PNDCL25) and Chieftaincy (Amendment) Law, 1993 (PNDCL 307).

[27] Eisenberg, S. (1998) We Will Call You If We Need You. Experiences of Women Working in Construction. Cornell University Press, Ithaca.

[28] Mackenzie, S., Kilpatrick, A.R. and Akintoye, A. (2000) UK Construction Skills Shortage Response Strategies and an Analysis of Industry Perceptions. Construction Management and Economics, 18, 853-862. http://dx.doi.org/10.1080/014461900433131

[29] Mitullah, W.V. and NjeriWachira, I. (2003) Informal Labour in the Construction Industry in Kenya: A Case Study of Nairobi. International Labour Organization.

[30] Offei-Nyako, K., Osei-Tutu, E., Fugar, F.D. and Adinyira, E. (2014) Skilled Artisanal Availability in the Ghanaian Construction Industry. Covenant Journal of Research in the Built Environment, 1, 1-9.

[31] Keteku-Atiemo, W. (2006) Rampant Failure of Buildings in an Era of Massive Shelter De- 
velopment in Ghana: Empowering the Informal Construction Labourer with Knowledge and Skill to Help in Providing a Solution to This Problem.

www.lth.se/fileadmin/hdm/alumni/papers/sdd2006/sdd2006-17.pdf

[32] Kings-Amadi, I. (2004) Appraisal of Land-Use Plan Implementation in River State: A Case Study of Port Harcourt Metropolis. Unpublished Master's Thesis, Rivers State University of Science and Technology, Institute of Geosciences and Space Technology, Port Harcourt.

[33] Mensah, C.A., Antwi, K.B. and Acheampong, P.K. (2013) Behavioural Dimension of the Growth of Informal Settlements in Kumasi City, Ghana. Research on Humanities and Social Sciences, 3, 1-10.

[34] Somiah, M.K., Osei-Poku, G. and Aidoo, I. (2015) Relative Importance Analysis of Factors Influencing Unauthorized Sitting of Residential Buildings in the Sekondi-Takoradi Metropolis of Ghana. Journal of Building Construction and Planning Research, 3, 117-126. http://dx.doi.org/10.4236/jbcpr.2015.33012

[35] Freiku, S.R. (2003) Kumasi Developments Are Getting Worse, Chaotic. Ghanaian Chronicle, 31 .

http://www.modernghana.com/news/30669/1/kumasis-developmentGetting-Worse-Chaotic .html for you:

Accepting pre-submission inquiries through Email, Facebook, LinkedIn, Twitter, etc. A wide selection of journals (inclusive of 9 subjects, more than 200 journals)

Providing 24-hour high-quality service

User-friendly online submission system

Fair and swift peer-review system

Efficient typesetting and proofreading procedure

Display of the result of downloads and visits, as well as the number of cited articles

Maximum dissemination of your research work

Submit your manuscript at: http://papersubmission.scirp.org/

Or contact jbcpr@scirp.org 